\title{
THE CHARACTERISTICS OF ONLINE VERSION OF NATIONAL NEWSPAPERS IN INDONESIA AND THE PHILIPPINES
}

\author{
Jandy E. Luik \\ Jurusan Ilmu Komunikasi, Fakultas Komunikasi \\ Universitas Kristen Petra \\ email: jandyluik@peter.petra.ac.id or http://edipson.wordpress.com/
}

\begin{abstract}
ABSTRAK
Media online menyajikan cara baru dalam menyiarakan informasi. Di era reformasi, suratkabar/koran menyediakan cara baru untuk mewartakan melalui media online. Karakteristiknya mencakup, hipertektualitas, multimedia dan interaktif. Semua itu dijadikan sarana menjembatani pertukaran informasi. Tiga koran di Indonesia dan di Philipina dipilih untuk diteliti dengan menggunakan media online. Temuannya adalah ternyata media koran versi online menggunakan karakteristik yang berbeda. Hipertektualitas menyisakan persoalan isi, multimedia.mencapai tingkatan konvergensi dan adaptasi interaksi masih belum sepenuhnya berhasil.
\end{abstract}

Kata kunci: karakteristik, media online

\section{INTRODUCTION}

The emergence of online media, particularly online news site, becomes valuable when human kinds have to fulfill two basic needs in information: to gain understanding about an event and to share the information (Craig, 2005). When the event happens, people who are interested in it will try to find related information. For example, when Soeharto, the former Indonesian president, passed away, I tried to explore the World Wide Web to access information related to that event. I could choose to read the chronology of his last minutes or I could choose another reading on his track record and people's opinion about him. It is a need to share the information among others, so I posted some information to my blog and my friend sent SMS to share this information. These needs are fulfilled at real-time when we have supporting information and communication technology.

The shifting of internet to be a mass medium promoted the growth of online news site. Web and browser were able to be integrated to the internet and support the availability of news in online version (Coorough, 2001 \& Ward, 2002). According to the American Journalism Review, in 1994 only 20 newspapers in the entire world had Web sites. Less than five years later there were more than 5,000 newspaper Web sites (Craig, 2005). Currently, online news sites are not limited to newspaper but in broadcasting. Moreover, online news sites could be online-only without counterpart.

Surely journalism remains the core of this rapid development. The intention to report news as soon and accurately as possible has not changed. However, technology, particularly digitalization, improves the way of journalists to do their job. Digital 
technology also improves the expectation of the audience. Therefore, journalism in online is different from the print and broadcast journalism.

The presence of online media is breaking down the linearity to read printed news. When we read a newspaper we start to read it from the beginning to the end and if we want to gain more information, we have to finish the first one before changing the reading. Whereas, in the broadcasting, we have to stay focus on the particular story. In the online version, we can make it linear or nonlinear with not to start in the beginning (Stovall, 2003). We can pause at certain part of the text and jump to another text to gain more information.

Along with the nonlinear, multi response will come from our sense. Since the presentation is not only refers to one sense, then it should increase the reception. Furthermore, the lack of space limitation is able to make provider confident with space-capacity (Stovall, 2003). Digitalization and space-ability contribute to the multi format of presentation.

Simultaneously, users' participations are increasing. Users are not remaining passive but becoming more active in choosing the news, giving prompt feedback, or even personalizing a particular site.

The decision of newspapers to go online should consider some aspects. Going online is not only a matter caused by the fact that we are entering the information age but more to be based on necessities of being online. Therefore, the needs or purposes of going online will determine the characteristics of particular online news site.

This paper will present characteristics of online sections in Indonesian and the Philippines' national newspapers. This study tries to understand the development of online media, in particular as a response of technology features in several leading newspapers in both countries.

\section{DISCUSSION}

\section{Online Version of National Newspaper}

Online version of newspaper means that the newspaper, or could be said traditional media, provide a website to put the news. Basically, the usage of web by the newspapers is different. Simplifying the distinction, it could be as a duplicate of the print one, or different from the print.

Each medium provides a kind of "hidden" ground which influences the content of communication. Consequently, this new media requires different way to present the news.

The presence of Internet and World Wide Web could be an accelerator of McLuhan's global village. Therefore, it brings the impact to the notion of local, national, and international. However, this research does not focus on the coverage of the newspaper, especially in their printed version. The usage of national newspaper is needed to examine the usage of technological features in the scale of nation-wide coverage.

To limit this paper and regarding to the time frame, three newspapers are selected from both countries. Kompas (www.kompas.com-beta version), Media Indonesia (www.mediaindonesia.com), and Jawa Pos (www.jawapos.com) are selected 
from Indonesian online news. For the Philippines, there are Philippine Daily Inquirer (www.inquirer.net), Philippine Star (www.philstar.com), and The Manila Times (www.manilatimes.net).

\section{Characteristic of Online News Site}

Online journalists could choose various kinds of websites based on their functionalities. The model to describe them has been elaborated by Mark Deuze (2001) in his paper to model the first generation of news media on the World Wide Web. Four functionality of online journalism are Mainstream News Sites, Index and Category Sites, Meta and Comments Sites, and Share and Discussion Sites. Contentconnectivity and closed-open participatory communication become the two bases for this model.

In this particular case, all the sites are categorized as Mainstream News Site. The mainstream news site is more to serve the editor's agendas and offer a selection of editorial content. Participatory communication from users could not be as free as sites for sharing and discussion.

In addition, the online journalist has to make decisions on which media format best tell a certain story, has to allow room for options for the public to respond, interact or even customize certain stories and must consider ways to connect the story to other stories, archives, resources and so on through hyperlink (Deuze, 2001). These characteristics are multimediality, interactivity, and hypertextuality.

Simply, hypertextuality is the ability to link or make interconnection between texts. The notion proposed by Bush (1945) about the work of human brain based on association and described a theoretical machine called "memex" show the need and pioneering of interconnectivity. Later, Nelson coined the term 'hypertext' (Deuze, 2001). This hypertext is categorized in two kinds: internal (interconnection within the text's domain) and external (interconnection to text located elsewhere in the Internet).

Multimediality in news sites is as a result of convergence of media modalities (where multimedia can be seen as the sum of different media formats) or as a divergent paradigm (where all parts of the site are developed from a multimedia starting point, offering the end-users several ways into and through the site's contents).

Interactivity in online news is categorized as navigational, functional, and adaptive. Navigational interactivity appears to break the linearity like tools for 'Back to Top', scroll up and down. Functional interactivity offers viewers to be more active in responding the news with tools direct mailto, Buletin Board System, and moderated discussion. However, the news provider is considered to have more power to control the news or the discussion. While at the last kind of interactivity, the viewers will become independent to choose or design their own site news and give opinion like in the chat room.

The writer observes six websites representing each national newspaper for two weeks. By the usage of the three characteristics, the writer is able to get information about the particular website and compare it with the other websites. The result serves as a description about the usage of web and its related technology. 


\section{Indonesian and the Philippines Online News}

Interconnection between texts in the websites becomes valuable since the notion of how human brain's work is like web. Most of the sites are considered to provide internal hypertextuality. Some of the website like Kompas.com and Media Indonesia.com provide external link. However, these links are not totally parts of the interconnection with the text. They are more to the consequence of business group or link to the advertisements. For instance in the Media Indonesia, we can make a link to the MetroTV's Kick Andy. In Kompas.com, external link could be found in the lowest part of the front page which is mostly to the member of the group. Jawa Pos dotcom provides the external link to the member of the group like Indo Pos (http://www.indopos.co.id/) and Radar Jogja (http://jawapos.com/index.php?act=radar\&id=85).

Therefore, regarding interconnection between texts, in this particular case is the news, these sites mainly focus on the internal link. Kompas.com provides related article (based on keyword) when user open particular news. For instance, the sport news about Arsenal in English Premiership League could be traced by opening news about Arsenal and the website will provide related articles. Similarity happens to Media Indonesia.com but sometimes they add broad links which is not only to the particular sport but general sport. However, Jawa Pos dotcom prefers to use link to open the complete news or open main sections on the web.

Although the current status is beta, Kompas.com maximizes the potential of multimediality. Simply, it is not only summing-up of text and image in the web but they add Kompas-TV (http://tv.kompas.com/). The converging of text, image, animation, audio, and moving image in web graphic bring up multi responses to our senses.

This level of convergence is not adapted yet by the other two websites. Jawapos.com and Media Indonesia.com focus on the picture and text on their respective site. However, there are animations in the sites. Animation technique is used to highlight certain section of the site or in the advertisement.

Interactivity of the three Indonesian websites is varied to either navigational or functional. Jawa Pos dotcom uses navigational interactivity on their website. User is able to go forward, back to home page or jump to other news, scroll up and down. These features are mostly to avoid the ability of user to get lost or re-type the web address when exploring it.

Kompas.com and Media Indonesia.com prefer to provide functional interactivity. Users are able to make more interaction within the site such as giving comments to the news. However, these comments should follow the rules of the media or moderated. Also, the email addresses of the editors or the reporters are not provided in the web.

Three Philippines newspapers use internal hypertextuality in their respective website. Inquirer.net makes internal links to the sections like news, sports, showbiz and style, and technology. Links to related news are provided by this website in the "Related Story" box on the right side of the particular news. Furthermore, external links are available but mostly to the advertisements and internal group. Internal links in Philstar.com are presented to serve the connectivity within the sections and the news. External links in this site consist of advertisements and their other publications: Pilipino Star Ngayon, Kasaligan Gyud Banat News, The Freeman, and 
People Asia. The Manila Times provides link to the external site like The Manila Times College and advertisements. Internal linkage of the site refers to all the inside section of the sites.

These sites mainly focus on the internal hypertextuality. As in the three Indonesian's site, the effort to reach external hypertextuality is started yet. In multimediality, these websites decide to use convergence but in different level. Inquirer.net combines the text, image, animation, sound and moving image into their website. Inquirer.net VDO (http://www.inquirer.net/vdo/player.php) which provide audio-video news, Inquirer.net Podcasts (http://newsinfo.inquirer.net/podcasts/) which provide audio-only news, and Inquirer.net Weather Report (http://www.inquirer.net/ mapapi/weather/) with the use of map-based interface. This weather report combines the service from Google and Philippine Atmospheric, Geophysical and Astronomical Services Administration (PAGASA).

Philstar.com and The Manila Times use different level of convergence. Both focus to the image and text. The animations are appearing in the form of advertisements. Interactivity in the three websites is categorized either to navigational or functional. Functional interactivity in Inquirer.net is mostly provided in "Article Services", normally in the right-side box of the news. Feedbacks in Philstar.com are presented in the lower part of particular news. Also, the function of "Print Article", "e-Mail Article", and "e-Mail Editor" are provided.

The Manila Times provide space for feedback but not refer the particular stories. Users should fill the feedback's requirements of ID and choose subjects like: report dead-links, report errors/corrections, advertising inquiry, subscription, site comments, letter to the editor, and others. Therefore, it is considered as navigational interactivity.

These three online versions depict different levels of characteristics. Mostly the websites provide internal hypertextuality to their stories. If these interconnections only refer to the internal, then one could make a question about worldwide ability by this online technology. Consequently, the notion of how human brain works is not reached yet. There is effort to create external but the problem of copyright and business interest could be the biggest barrier to establish it. However, some websites create external link throughout their business group or forms of cooperation/partnership.

Convergence-multimediality is adapted in different level by these online versions of newspapers. Kompas.com and Inquirer.net decide to add various media formats in their respective website. The other websites decide to use different level of convergence. Referring back to the need of multimedia, as the notion of Guay (in Deuze, 2001) and Craig, the multimedia elements are used for certain reason and purpose or add something unique to a story. Instead of the different level of convergence in those websites, each provider surely establishes the needs and reasons of being online.

Interactivity seems difficult to reach the adaptive level. Navigational and functionality are the choice of the websites. Navigational level tend to maintain the practice of "I write, you read" tradition, with the respect of the professional who make best news. The functional interactivity gives more space to the user to become active. The user could leave their feedback and follow-up the stories. The ultimate level of 
interactivity that is offering more interactivity like chatrooms and personal customization of website are not presented yet.

The next question is remaining level like external hypertextuality and the potentiality of adaptive interactivity. Since the concern of the mainstream news site is content from editorial desk rather than connectivity, it looks difficult to be applied. However, it is not possible to be applied regarding the growth of needs of human kind. As started yet by several websites, joint cooperation, news-sharing agreement, or any cooperation among the provider could lead to this interconnectivity. Adaptive interactivity could be realized by provide online chats with reporters or newsmakers and provide personalized news (Stovall, 2003).

Results that come-out from this paper do not judge that the news without "extraordinary" treatment in their web is not good. Further researches are required to claim for it. As mentioned above, the use of technology should not only be based on the trend; it should be based on the needs of particular provider. These needs could be based on the concentration of respective institution or the interest from their respective reader to this new way of presenting news.

However, the point is all these media is anticipating the coming of new media era in their particular society. As we realize the current condition of information and technology infrastructure, we could not stop or losing hope because it remains growing. Moreover, the way of human to consume the news or to fulfill the needs of information will grow.

\section{CONCLUSION}

Hypertextuality, Multimediality, and Interactivity are applied in different level from the three National Newspapers' online version in Indonesia and the Philippines. Internal hypertextuality dominates the presentation of news in online version. Highest level of convergence is applied by Inquirer.net and Kompas.com, while Jawa Pos dotcom, Media Indonesia.com, Philstar.com, and The Manila Times use moderate level of convergence. Inquirer.net, Kompas.com, Media Indonesia.com, and Philstar.com expand the website up to functional interactivity, while the others decide to use navigational.

Regarding this differences, the news providers should be aware of the growth of new medium and rapid development in the information age because of its own 'languages' or characteristics. The needs of respective society will go along. Therefore, the need to maximize the potential of this new medium will lead to enhance journalism itself, enhance society's needs of information and enhance sustainability of respective media institution. 


\section{REFERENCES}

Bush, V. 1945. As We May Think. Atlantic Monthly in the web, accessed: June 26, 2007. http://www.theatlantic.com/doc/194507/bush.

Coorough, C. 2001. Multimedia and the Web: Creating Digital Excitement. OrlandoUSA: Harcourt College Publisher.

Craig, R. 2005. Online Journalism: Reporting, Writing, and Editing for New Media. Canada: Thompson-Wadsworth.

Deuze, M. 2001. Online Journalism: Modelling the First Generation of News Media on the World Wide Web. First Monday, Vol 6, Number 10.

Elsom-Cook, M. 2001. Principles of Interactive Multimedia. England: McGraw-Hill Publishing Company.

Kompas online version (beta version). http://www.kompas.com/. Access period: late January to mid-February 2008.

Jawa Pos online version. http://jawapos.com/index.php?act=utama. Access period: late January to mid-February 2008.

Media Indonesia online version. http://www.mediaindonesia.com/. Access period: late January to mid-February 2008.

McLuhan, M. 1964. Understanding Media: The Extension of Man. New York: McGraw-Hill.

Philippine Daily Inquirer online version. http://www.inquirer.net/. Access period: late January to mid-February 2008.

Quinn, S. \& Filak, V.F. 2005. Convergent Journalism: an Introduction-Writing and Producing Across Media. England: Focal Press an Imprint of Elsevier Science.

Stovall, J.G. 2003. Web Journalism: Practice and Promise of a New Medium. Boston: Pearson Allyn and Bacon.

The Manila Times online version. http://www.manilatimes.net/. Access period: late January to mid-February 2008.

The Philippine Star online version. http://philstar.com/index.php. Access period: late January to mid-February 2008.

Ward, M. 2002. Journalism Online. England: Focal Press an Imprint of Elsevier Science 